\title{
Hymenobacter psychrophilus sp. nov., a psychrophilic bacterium isolated from soil
}

Correspondence

Rosa Margesin

Rosa.Margesin@uibk.ac.at

\author{
De-Chao Zhang, ${ }^{1}$ Hans-Jürgen Busse, ${ }^{2}$ Hong-Can Liu, ${ }^{3}$ Yu-Guang Zhou, ${ }^{3}$ \\ Franz Schinner ${ }^{1}$ and Rosa Margesin ${ }^{1}$
}

\author{
${ }^{1}$ Institute of Microbiology, University of Innsbruck, Technikerstrasse 25, A-6020 Innsbruck, Austria \\ ${ }^{2}$ Institute of Bacteriology, Mycology and Hygiene, University of Veterinary Medicine Vienna, \\ Veterinärplatz 1, A-1210 Vienna, Austria \\ ${ }^{3}$ China General Microbiological Culture Collection Center and State Key Laboratory of Microbial \\ Resources, Institute of Microbiology, Chinese Academy of Sciences, Beijing 100101, PR China
}

\begin{abstract}
A non-motile, rod-shaped, red-pigmented bacterium, designated strain $\mathrm{BZ} 33 \mathrm{r}^{\top}$, was isolated from soil of an industrial site. Cells stained Gram-negative and were aerobic and psychrophilic, showing good growth at $1-20{ }^{\circ} \mathrm{C}$. Phylogenetic analysis based on $16 \mathrm{~S}$ rRNA gene sequences showed that strain $\mathrm{BZ} 33 \mathrm{r}^{\top}$ was related to members of the genus Hymenobacter and had highest sequence similarity with Hymenobacter aerophilus DSM $13606^{\top}(97.5 \%)$. The predominant cellular fatty acids were anteiso- $\mathrm{C}_{15: 0}(20.3 \%)$, summed feature $3\left(\mathrm{C}_{16: 1} \omega 7 \mathrm{c}\right.$ and/or iso- $\mathrm{C}_{15: 0}$ $2-\mathrm{OH} ; 20.2 \%$ ), iso- $\mathrm{C}_{15: 0}\left(20.0 \%\right.$ ), summed feature 4 (iso- $\mathrm{C}_{17: 1} \mathrm{I}$ and/or anteiso- $\mathrm{C}_{17: 1} \mathrm{~B}$; $8.2 \%)$ and $\mathrm{C}_{16: 1} \omega 5 c(7.9 \%)$. Strain $\mathrm{BZ}_{3} \mathrm{r}^{\top}$ had MK-7 as the major menaquinone. The polyamine pattern contained sym-homospermidine as the major compound with moderate amounts of spermidine. Phosphatidylethanolamine, three unknown aminophospholipids, two unknown aminolipids, two unknown glycolipids and five unknown polar lipids were present in the polar lipid profile. The $\mathrm{G}+\mathrm{C}$ content of the DNA was $61.6 \mathrm{~mol} \%$. On the basis of phenotypic characteristics, phylogenetic analysis and DNA-DNA relatedness data, strain $B Z 33 r^{\top}$ is considered to represent a novel species of the genus Hymenobacter, for which the name Hymenobacter psychrophilus sp. nov. is proposed. The type strain is $\mathrm{BZ}_{33 r^{\top}}\left(=\mathrm{DSM} 22290^{\top}\right.$ $=$ CGMCC $1.8975^{\top}=$ LMG $25548^{\top}$ ).
\end{abstract}

The genus Hymenobacter, which belongs to the phylum Bacteroidetes, order Sphingobacteriales, family Cytophagaceae, was proposed by Hirsch et al. (1998) to accommodate aerobic, Gram-stain-negative, rod-shaped, red-pigmented bacteria that contain menaquinone MK-7 and have phosphatidylethanolamine as the main phospholipid. According to an emended description (Buczolits et al., 2006), members of the genus Hymenobacter contain sym-homospermidine as the major compound in the polyamine profile and, compared with other taxa of the Bacteroidetes, a high DNA $\mathrm{G}+\mathrm{C}$ content (55-65 mol\%) . The fatty acid profile consists predominantly of branched components. At the time of writing, the genus Hymenobacter comprised 14 recognized species: Hymenobacter roseosalivarius (type species of the genus; Hirsch et al., 1998), H. actinosclerus (Collins et al., 2000), H. aerophilus (Buczolits et al., 2002), H. chitinivorans, $H$. gelipurpurascens, $H$. norwichensis and $H$. ocellatus

The GenBank/EMBL/DDBJ accession number for the 16S rRNA gene sequence of strain $\mathrm{BZ33r}^{\top}$ is $\mathrm{GQ131579.}$

A supplementary figure and a supplementary table are available with the online version of this paper.
(Buczolits et al., 2006), $H$. rigui (Baik et al., 2006), $H$. xinjiangensis (Zhang et al., 2007), H. soli (Kim et al., 2008), H. psychrotolerans (Zhang et al., 2008), H. tibetensis (Dai et al., 2009), H. deserti (Zhang et al., 2009) and H. daecheongensis (Xu et al., 2009). Many members of the genus have been isolated from environmental samples such as soil (Hirsch et al., 1998; Buczolits et al., 2006; Zhang et al., 2007, 2009; Kim et al., 2008; Dai et al., 2009), permafrost sediment (Zhang et al., 2008), stream sediment (Xu et al., 2009), wetland freshwater (Baik et al., 2006) and air (Buczolits et al., 2002, 2006). Three species, H. actinosclerus, H. xinjiangensis and $H$. tibetensis, have been reported to be resistant to UV radiation (Dai et al., 2009). In this study, we report the characterization of a novel bacterium of the genus Hymenobacter isolated from an industrial site.

Strain $\mathrm{BZ}_{3} \mathrm{r}^{\mathrm{T}}$ was isolated from soil containing high levels of heavy oil and heavy metals at an industrial site in Bozen, South Tyrol (Italy). Soil was collected under sterile conditions in spring 2008. A sample of $10 \mathrm{~g}$ was shaken (150 r.p.m.) with $90 \mathrm{ml}$ sterile $1 \%$ sodium pyrophosphate for $20 \mathrm{~min}$. Appropriate dilutions, prepared with sterile saline solution $(0.9 \% \mathrm{NaCl})$, were plated $(0.1 \mathrm{ml})$ on $\mathrm{R} 2 \mathrm{~A}$ 
agar $\quad(0.05 \%$ yeast extract, $0.05 \%$ peptone, $0.05 \%$ Casamino acids, $0.05 \%$ glucose, $0.05 \%$ starch, $0.03 \%$ sodium pyruvate, $0.03 \% \mathrm{~K}_{2} \mathrm{HPO}_{4}, 0.005 \% \mathrm{MgSO}_{4}$ and $1.5 \%$ agar, $\mathrm{pH} 7$; Reasoner \& Geldreich, 1985) and incubated at $20{ }^{\circ} \mathrm{C}$. One of the purified cultures was redpigmented and was designated strain $\mathrm{BZ} 33 \mathrm{r}^{\mathrm{T}}$. H. aerophilus DSM $13606^{\mathrm{T}}$ was routinely grown on nutrient agar $(0.5 \%$ peptone, $0.3 \%$ beef extract and $1.5 \%$ agar, $\mathrm{pH} 7.0$ ) at $20{ }^{\circ} \mathrm{C}$ and used as a reference strain.

DNA was extracted and purified as described by Sambrook et al. (1989). The gene encoding $16 \mathrm{~S}$ rRNA was amplified by PCR with two universal primers (Zhang et al., 2006). PCR products were cloned in pGEM-T vectors by using the pGEM-T easy vector systems (Promega) according to the manufacturer's instructions. Sequencing reactions were performed as described by Zhang et al. (2006). The nearly complete 16S rRNA gene sequence $(1511 \mathrm{bp})$ of strain $\mathrm{BZ}_{3} \mathrm{r}^{\mathrm{T}}$ was analysed by using the FASTA algorithm. Phylogenetic analysis with the program MEGA version 3.0 (Kumar et al., 2004) showed that strain $\mathrm{BZ}_{3} \mathrm{r}^{\mathrm{T}}$ grouped with members of the genus Hymenobacter and formed a distinct cluster with $H$. aerophilus DSM $13606^{\mathrm{T}}$ (97.5\% $16 \mathrm{~S}$ rRNA gene sequence similarity) and $H$. actinosclerus CIP $106628^{\mathrm{T}}(96.9 \%)$ with $100 \%$ bootstrap support in the neighbour-joining tree (Fig. 1). In addition, a similar topology was found in the tree generated with the maximum-likelihood method via the PHYLIP 3.69 package (Felsenstein, 2009) after sequence alignment by using CLUSTAL X, version 1.8 (Thompson et al., 1997).

Strain $\mathrm{BZ} 33 \mathrm{r}^{\mathrm{T}}$ was routinely cultured on R2A agar medium at $20{ }^{\circ} \mathrm{C}$ and maintained as a suspension in skimmed milk $(10 \%, w / v)$ at $-80{ }^{\circ} \mathrm{C}$. Cell morphology was examined by phase-contrast microscopy $(\times 1000$; Leitz Diaplan $)$ of cells grown on R2A agar plates at $20{ }^{\circ} \mathrm{C}$. Colonial morphology was also observed on R2A agar plates. The API M system was used to evaluate cell motility. The Gram reaction was tested by Gram staining and was confirmed by the $\mathrm{KOH}$ lysis test. Catalase activity was determined by bubble production in $3 \%(\mathrm{v} / \mathrm{v}) \mathrm{H}_{2} \mathrm{O}_{2}$ and oxidase activity was determined by using $1 \%(\mathrm{w} / \mathrm{v}) \mathrm{N}, N, N^{\prime}, N^{\prime}$-tetramethyl- $p$ phenylenediamine. API strips (API $20 \mathrm{E}$, API $20 \mathrm{NE}$ and
API ZYM; bioMérieux) incubated at $20{ }^{\circ} \mathrm{C}$ were used according to the manufacturer's instructions to determine the physiological and biochemical characteristics and enzyme activities of strain $\mathrm{BZ} 33 \mathrm{r}^{\mathrm{T}}$ and of the reference strain $H$. aerophilus DSM $13606^{\mathrm{T}}$. Activities of $\beta$-galactosidase, amylase and protease were additionally tested by using R2A agar plates supplemented with appropriate substrates (Margesin et al., 2003). Growth at $1-30{ }^{\circ} \mathrm{C}$ was assessed on R2A agar plates and in R2A liquid medium with shaking at 150 r.p.m. Growth at $\mathrm{pH} 5-9$ and in the presence of $0-5 \%(\mathrm{w} / \mathrm{v}) \mathrm{NaCl}$ was determined on $\mathrm{R} 2 \mathrm{~A}$ agar plates. Susceptibility to antibiotics was determined on R2A agar plates supplemented with various antibiotics and incubated at $20{ }^{\circ} \mathrm{C}$. The features that serve to differentiate strain $\mathrm{BZ}_{3} \mathrm{r}^{\mathrm{T}}$ from the phylogenetically most closely related members of the genus Hymenobacter are given in Table 1. Morphological, physiological and biochemical characteristics of strain $\mathrm{BZ}_{3} 3 \mathrm{r}^{\mathrm{T}}$ are given in the species description and in Table 1.

Respiratory quinones were extracted and purified according to Collins (1985) and were analysed by HPLC (Wu et al., 1989), by using menaquinone MK-7 from $H$. aerophilus DSM $13606^{\mathrm{T}}$ as a reference. Strain $\mathrm{BZ} 33 \mathrm{r}^{\mathrm{T}}$ contained MK-7 as the major menaquinone.

Cellular polar lipids were extracted and analysed on silica gel plates (Kieselgel 60 F; Merck) by TLC (Kates, 1986). Phosphatidylethanolamine, three unknown aminophospholipids, two unknown aminolipids, two unknown glycolipids and five unknown polar lipids were detected in the polar lipid profile (Supplementary Fig. S1, available in IJSEM Online).

For analysis of fatty acid methyl esters, strain $\mathrm{BZ}_{3} 3 \mathrm{r}^{\mathrm{T}}$ and H. aerophilus DSM $13606^{\mathrm{T}}$ were grown on trypticase soy agar plates at $20{ }^{\circ} \mathrm{C}$ for 3 days. Analysis was performed according to the standard protocol of the MIDI (Microbial Identification) system (Sasser, 1990). The predominant cellular fatty acids were anteiso- $\mathrm{C}_{15: 0}(20.3 \%)$, summed feature $3\left(\mathrm{C}_{16: 1} \omega 7 c\right.$ and/or iso- $\left.\mathrm{C}_{15: 0} 2-\mathrm{OH} ; 20.2 \%\right)$, iso$\mathrm{C}_{15: 0}(20.0 \%)$, summed feature 4 (iso- $\mathrm{C}_{17: 1} \mathrm{I}$ and/or anteiso- $\left.\mathrm{C}_{17: 1} \mathrm{~B} ; 8.2 \%\right)$ and $\mathrm{C}_{16: 1} \omega 5 c(7.9 \%)$. The detailed fatty acid profile of strain $B Z 33 r^{\mathrm{T}}$ was in agreement with

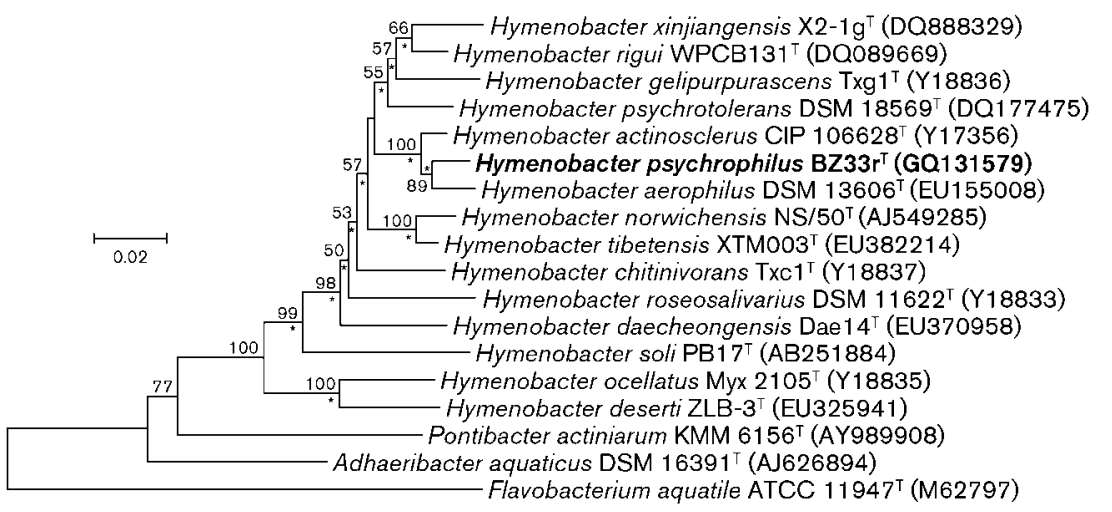

Fig. 1. Neighbour-joining tree, based on $16 \mathrm{~S}$ rRNA gene sequence data, showing the phylogenetic position of strain $\mathrm{BZ}_{3} \mathrm{r}^{\mathrm{T}}$, recognized members of the genus Hymenobacter and representatives of some related taxa. Asterisks indicate nodes that were also found in the maximum-likelihood tree. Flavobacterium aquatile ATCC $11947^{\top}$ was used as an outgroup. Bootstrap values are shown as percentages of 1000 replicates and are shown for branches with $\geqslant 50 \%$ support. GenBank accession numbers are given in parentheses. Bar, $2 \%$ sequence divergence. 
Table 1. Phenotypic characteristics that differentiate strain $\mathrm{BZ} 33 \mathrm{r}^{\top}$ from the type strains of phylogenetically related $H_{y m e n o b a c t e r}$ species

Strains: 1, BZ33r ${ }^{\mathrm{T}}$ (data from this study); 2, H. aerophilus DSM $13606^{\mathrm{T}}$ (this study); 3, H. actinosclerus CIP 106628 ${ }^{\mathrm{T}}$ (Collins et al., 2000; Buczolits et al., 2002); 4, H. gelipurpurascens $\operatorname{Txg}^{\mathrm{T}}$ (Buczolits et al., 2006); 5, H. psychrotolerans DSM $18569^{\mathrm{T}}$ (Zhang et al., 2008). +, Positive; -, negative; $\mathrm{W}$, weakly positive; ND, no data available. All strains are positive for activities of alkaline phosphatase and leucine arylamidase. All strains are negative for activities of lipase (C14), trypsin, $\alpha$-chymotrypsin, $\alpha$-galactosidase, $\beta$-galactosidase, $\beta$-glucuronidase, $\beta$-glucosidase, $\alpha$-mannosidase, $\alpha$ fucosidase and urease, indole production and assimilation of adipate, gluconate, citrate and $N$-acetylglucosamine (except for $H$. actinosclerus CIP $106628^{\mathrm{T}}$, which assimilates these compounds weakly).

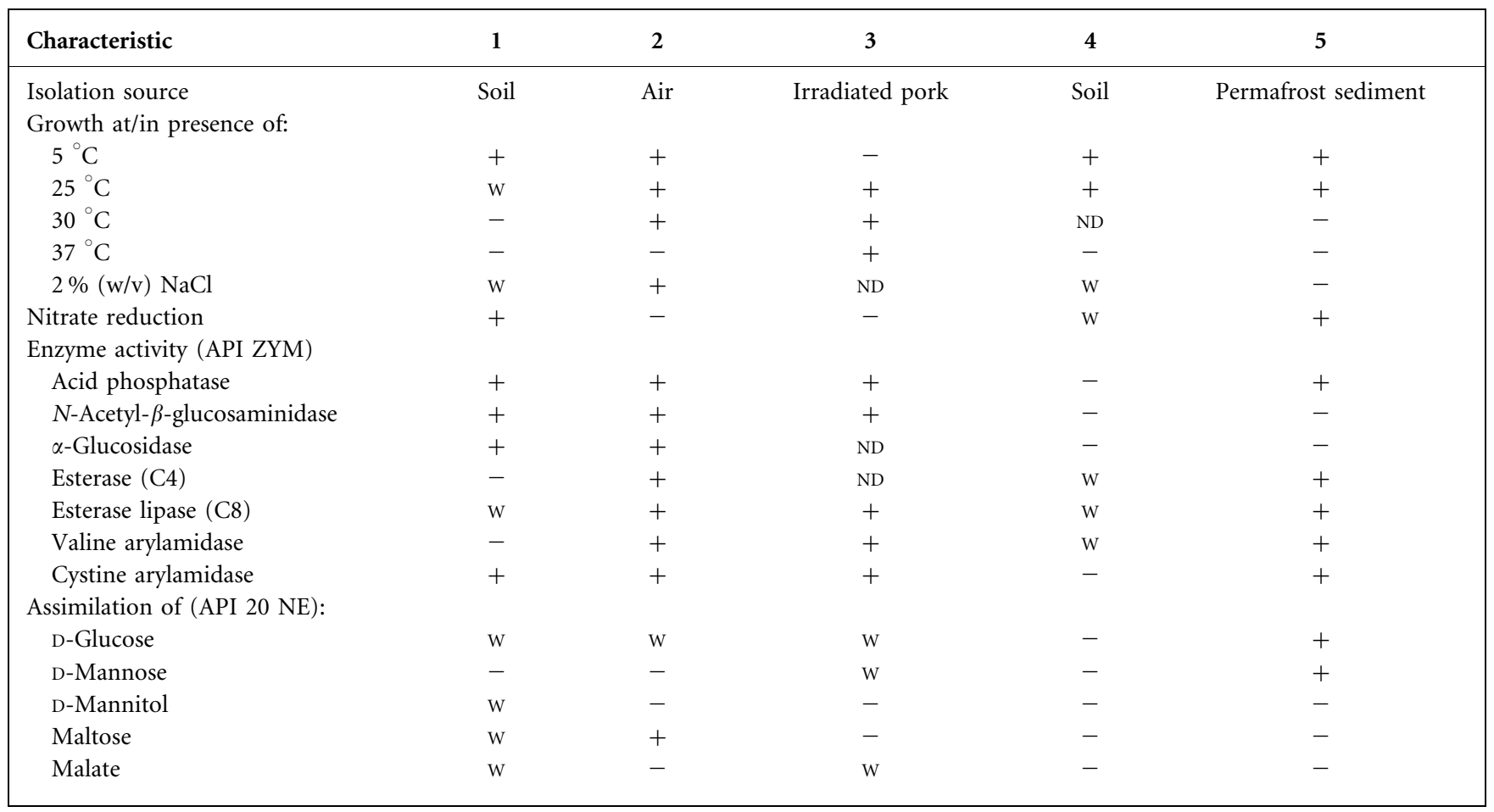

those of recognized Hymenobacter species (Buczolits et al., 2002, 2006; Zhang et al., 2008) (Supplementary Table S1).

For polyamine analysis, strain $\mathrm{BZ}_{33} \mathrm{r}^{\mathrm{T}}$ was grown in PYE medium $(0.3 \%$ yeast extract, $0.3 \%$ peptone, $\mathrm{pH} 7)$. Polyamines were extracted as described by Busse \& Auling (1988) and were analysed as described by Busse et al. (1997) and Stolz et al. (2007). The polyamine pattern of strain $\mathrm{BZ}_{3} \mathrm{r}^{\mathrm{T}}$ consisted of sym-homospermidine [39.9 $\mu \mathrm{mol}\left(\mathrm{g}\right.$ dry cell mass) $\left.{ }^{-1}\right]$ as the major compound, moderate amounts of spermidine $[6.5 \mu \mathrm{mol}$ (g dry cell mass $\left.)^{-1}\right]$ and spermine $\left[3.2 \mu \mathrm{mol}\right.$ (g dry cell mass) $\left.^{-1}\right]$ and a trace amount of putrescine $[0.2 \mu \mathrm{mol}(\mathrm{g}$ dry cell mass $)^{-1}$. This polyamine pattern is in good agreement with that given in the emended description of the genus Hymenobacter (Buczolits et al., 2006).

The DNA G $+\mathrm{C}$ content was determined by the thermal denaturation method with Escherichia coli $\mathrm{K}-12$ as reference, and DNA-DNA hybridization experiments were performed by the liquid renaturation method (De Ley et al., 1970) as modified by Huß et al. (1983). The two experiments were carried out by using a model Lambda $35 \mathrm{UV} / \mathrm{Vis}$ spectrometer equipped with a temperature program controller (Perkin-Elmer). The DNA G+C content of strain $\mathrm{BZ33r} \mathrm{r}^{\mathrm{T}}$ was $61.6 \mathrm{~mol} \%$, within the range given for the genus. The level of DNA-DNA relatedness between strain BZ33r ${ }^{\mathrm{T}}$ and H. aerophilus DSM $13606^{\mathrm{T}}$ was as low as $39.2 \%$, much lower than the threshold $(70 \%)$ recommended for species demarcation (Wayne et al., 1987). These data clearly demonstrate that the novel strain represents a species distinct from $H$. aerophilus. Levels of 16S rRNA gene sequence similarity of $<97.0 \%$ were found between strain $\mathrm{BZ} 33 \mathrm{r}^{\mathrm{T}}$ and the type strains of recognized species of the genus Hymenobacter. It has been suggested that, in bacterial strains sharing $<97 \% 16 \mathrm{~S}$ rRNA gene sequence similarity, levels of DNA-DNA relatedness are $<70 \%$ (Stackebrandt \& Goebel, 1994; Stackebrandt \& Ebers, 2006). Therefore, strain $\mathrm{BZ}_{3} \mathrm{r}^{\mathrm{T}}$ is genotypically distinct from all recognized species of the genus Hymenobacter.

The results presented above demonstrate that strain $\mathrm{BZ33} \mathrm{r}^{\mathrm{T}}$ is a psychrophilic member of the genus Hymenobacter (16S rRNA gene sequence analysis, quinone system and polyamine pattern), showing good growth at 1$20{ }^{\circ} \mathrm{C}$ (highest cell yields at $1-10{ }^{\circ} \mathrm{C}$ ), weak growth at $25{ }^{\circ} \mathrm{C}$ and no growth at $30^{\circ} \mathrm{C}$. The strain can be differentiated easily from its closest phylogenetic neighbours, $H$. aerophilus DSM $13606^{\mathrm{T}}$ and H. actinosclerus CIP $106628^{\mathrm{T}}$, by its 
ability to reduce nitrate, inability to grow at $30{ }^{\circ} \mathrm{C}$ and inability to produce valine arylamidase, as well as by its polar lipid profile (two unknown aminolipids and two unknown glycolipids) and the relative amounts of certain fatty acids (iso- $\mathrm{C}_{15: 0}$, summed feature 3 and summed feature 4). Therefore, based on the phenotypic, phylogenetic and genomic evidence presented, strain $\mathrm{BZ} 33 \mathrm{r}^{\mathrm{T}}$ is considered to represent a novel species of the genus Hymenobacter, for which the name Hymenobacter psychrophilus sp. nov. is proposed.

\section{Description of Hymenobacter psychrophilus sp. nov.}

Hymenobacter psychrophilus (psy.chro'phi.lus. Gr. adj. psychros cold; Gr. adj. philos liking, loving; N.L. masc. adj. psychrophilus cold-loving).

Cells are aerobic, Gram-stain-negative, non-motile and rod-shaped $\left(1-1.1 \times 2-7 \mu \mathrm{m}\right.$ after 6 days at $20{ }^{\circ} \mathrm{C}$ on R2A agar plates). Colonies on R2A agar are red, round, convex and with entire margins; colony diameter is $1 \mathrm{~mm}$ after 6 days at $20{ }^{\circ} \mathrm{C}$. Good growth occurs in liquid R2A medium and on agar plates at $1-20{ }^{\circ} \mathrm{C}$, with highest cell yields in liquid culture at $1-10{ }^{\circ} \mathrm{C}$. Growth is weak at $25{ }^{\circ} \mathrm{C}$ and absent at $30{ }^{\circ} \mathrm{C}$. Growth at $25{ }^{\circ} \mathrm{C}$ is absent in nutrient broth. On R2A agar plates, grows in the presence of $0-1 \%$ $(\mathrm{w} / \mathrm{v}) \mathrm{NaCl}$; growth in the presence of $2 \%(\mathrm{w} / \mathrm{v}) \mathrm{NaCl}$ is weak. Produces catalase and cytochrome oxidase. Negative for production of indole, $\mathrm{H}_{2} \mathrm{~S}$ and urease, utilization of citrate and hydrolysis of aesculin. Positive for nitrate reduction. Negative for activities of arginine dihydrolase, lysine dihydrolase, ornithine dihydrolase, tryptophan deaminase, trypsin, $\alpha$-chymotrypsin, lipase (C14), esterase (C4), valine arylamidase, $\alpha$-galactosidase, $\beta$-galactosidase, $\beta$-glucuronidase, $\beta$-glucosidase, $\alpha$-mannosidase and $\alpha$ fucosidase. Positive for activities of acid phosphatase, alkaline phosphatase, leucine arylamidase, naphthol-ASBI-phosphohydrolase, protease, amylase, cystine arylamidase, $\alpha$-glucosidase and $N$-acetyl- $\beta$-glucosaminidase. Activity of esterase lipase (C8) is weak. In the API $20 \mathrm{NE}$ system, assimilates D-glucose, D-mannitol, maltose and malic acid weakly. Does not assimilate L-arabinose, Dmannose, $\mathrm{N}$-acetylglucosamine, gluconate, citrate, capric acid, adipic acid or phenylacetic acid. Negative for fermentation of glucose, ribose, xylose, mannitol, maltose, lactose, sucrose, glycogen, inositol, sorbitol, rhamnose, melibiose, amygdalin and L-arabinose. Resistant to cyclosporin $\mathrm{A}\left(100 \mu \mathrm{g} \mathrm{ml}^{-1}\right)$, but sensitive to ampicillin $(50 \mu \mathrm{g}$ $\mathrm{ml}^{-1}$ ), kanamycin, streptomycin, rifampicin, tetracycline, penicillin G, chloramphenicol and trimethoprim (each at $100 \mu \mathrm{g} \mathrm{ml}{ }^{-1}$ ). The predominant cellular fatty acids are anteiso- $\mathrm{C}_{15: 0}$, summed feature $3\left(\mathrm{C}_{16: 1} \omega 7 c\right.$ and/or iso$\mathrm{C}_{15: 0} 2-\mathrm{OH}$ ), iso- $\mathrm{C}_{15: 0}$, summed feature 4 (iso- $\mathrm{C}_{17: 1} \mathrm{I}$ and/or anteiso- $\mathrm{C}_{17: 1} \mathrm{~B}$ ) and $\mathrm{C}_{16: 1} \omega 5 \mathrm{c}$. MK-7 is the major menaquinone. Phosphatidylethanolamine, three unknown aminophospholipids, two unknown aminolipids, two unknown glycolipids and five unknown polar lipids are present in the polar lipid profile. The polyamine pattern is composed of sym-homospermidine as the major compound, moderate amounts of spermidine and spermine and a trace amount of putrescine. The DNA G $+\mathrm{C}$ content of the type strain is $61.6 \mathrm{~mol} \%$.

The type strain, $\mathrm{BZ} 3 \mathrm{r}^{\mathrm{T}}\left(=\mathrm{DSM} 22290^{\mathrm{T}}=\mathrm{CGMCC}\right.$ $1.8975^{\mathrm{T}}=\mathrm{LMG} 25548^{\mathrm{T}}$ ), was isolated from soil from an industrial site in Bozen, South Tyrol, Italy.

\section{Acknowledgements}

This research work was supported by a grant from the Autonome Provinz Bozen, Südtirol. We thank P. Thurnbichler for technical assistance.

\section{References}

Baik, K. S., Seong, C. N., Moon, E. Y., Park, Y.-D., Yi, H. \& Chun, J. (2006). Hymenobacter rigui sp. nov., isolated from wetland freshwater. Int J Syst Evol Microbiol 56, 2189-2192.

Buczolits, S., Denner, E. B. M., Vybiral, D., Wieser, M., Kämpfer, P. \& Busse, H.-J. (2002). Classification of three airborne bacteria and proposal of Hymenobacter aerophilus sp. nov. Int J Syst Evol Microbiol 52, 445-456.

Buczolits, S., Denner, E. B. M., Kämpfer, P. \& Busse, H.-J. (2006). Proposal of Hymenobacter norwichensis sp. nov., classification of 'Taxeobacter ocellatus', 'Taxeobacter gelupurpurascens' and 'Taxeobacter chitinovorans' as Hymenobacter ocellatus sp. nov., Hymenobacter gelipurpurascens sp. nov. and Hymenobacter chitinivorans sp. nov., respectively, and emended description of the genus Hymenobacter Hirsch et al. 1999. Int J Syst Evol Microbiol 56, 2071-2078.

Busse, H.-J. \& Auling, G. (1988). Polyamine pattern as a chemotaxonomic marker within the Proteobacteria. Syst Appl Microbiol 11, 1-8.

Busse, H.-J., Bunka, S., Hensel, A. \& Lubitz, W. (1997). Discrimination of members of the family Pasteurellaceae based on polyamine patterns. Int J Syst Bacteriol 47, 698-708.

Collins, M. D. (1985). Isoprenoid quinone analysis in classification and identification. In Chemical Methods in Bacterial Systematics, pp. 267-287. Edited by M. Goodfellow \& D. E. Minnikin. London: Academic Press.

Collins, M. D., Hutson, R. A., Grant, I. R. \& Patterson, M. F. (2000). Phylogenetic characterization of a novel radiation-resistant bacterium from irradiated pork: description of Hymenobacter actinosclerus sp. nov. Int J Syst Evol Microbiol 50, 731-734.

Dai, J., Wang, Y., Zhang, L., Tang, Y., Luo, X., An, H. \& Fang, C. (2009). Hymenobacter tibetensis sp. nov., a UV-resistant bacterium isolated from Qinghai-Tibet plateau. Syst Appl Microbiol 32, 543-548.

De Ley, J., Cattoir, H. \& Reynaerts, A. (1970). The quantitative measurement of DNA hybridization from renaturation rates. Eur J Biochem 12, 133-142.

Felsenstein, J. (2009). PHYLIP (phylogeny inference package), version 3.69. Distributed by the author. Department of Genome Sciences, University of Washington, Seattle, USA.

Hirsch, P., Ludwig, W., Hethke, C., Sittig, M., Hoffmann, B. \& Gallikowski, C. A. (1998). Hymenobacter roseosalivarius gen. nov., sp. nov. from continental Antarctica soils and sandstone: bacteria of the Cytophaga/Flavobacterium/Bacteroides line of phylogenetic descent. Syst Appl Microbiol 21, 374-383.

Huß, V. A. R., Festl, H. \& Schleifer, K. H. (1983). Studies on the spectrophotometric determination of DNA hybridization from renaturation rates. Syst Appl Microbiol 4, 184-192. 
Kates, M. (1986). Techniques of Lipidology, 2nd edn. Amsterdam: Elsevier.

Kim, K.-H., Im, W.-T. \& Lee, S.-T. (2008). Hymenobacter soli sp. nov., isolated from grass soil. Int J Syst Evol Microbiol 58, 941-945.

Kumar, S., Tamura, K. \& Nei, M. (2004). MEGA3: integrated software for molecular evolutionary genetics analysis and sequence alignment. Brief Bioinform 5, 150-163.

Margesin, R., Gander, S., Zacke, G., Gounot, A. M. \& Schinner, F. (2003). Hydrocarbon degradation and enzyme activities of coldadapted bacteria and yeasts. Extremophiles 7, 451-458.

Reasoner, D. J. \& Geldreich, E. E. (1985). A new medium for the enumeration and subculture of bacteria from potable water. Appl Environ Microbiol 49, 1-7.

Sambrook, J., Frisch, E. F. \& Maniatis, T. (1989). Molecular Cloning: a Laboratory Manual, 2nd edn. Cold Spring Harbor, NY: Cold Spring Harbor Laboratory.

Sasser, M. (1990). Identification of bacteria by gas chromatography of cellular fatty acids, Technical Note 101. Newark, DE: MIDI Inc.

Stackebrandt, E. \& Ebers, J. (2006). Taxonomic parameters revisited: tarnished gold standards. Microbiol Today 33, 152-155.

Stackebrandt, E. \& Goebel, B. M. (1994). Taxonomic note: a place for DNA-DNA reassociation and $16 \mathrm{~S}$ rRNA sequence analysis in the present species definition in bacteriology. Int J Syst Bacteriol 44, 846849.

Stolz, A., Busse, H.-J. \& Kämpfer, P. (2007). Pseudomonas knackmussii sp. nov. Int J Syst Evol Microbiol 57, 572-576.

Thompson, J. D., Gibson, T. J., Plewniak, F., Jeanmougin, F. \& Higgins, D. G. (1997). The CLUSTAL_X windows interface: flexible strategies for multiple sequence alignment aided by quality analysis tools. Nucleic Acids Res 25, 4876-4882.

Wayne, L. G., Brenner, D. J., Colwell, R. R., Grimont, P. A. D., Kandler, O., Krichevsky, M. I., Moore, L. H., Moore, W. E. C., Murray, R. G. E. \& other authors (1987). International Committee on Systematic Bacteriology. Report of the ad hoc committee on reconciliation of approaches to bacterial systematics. Int J Syst Bacteriol 37, 463-464.

Wu, C., Lu, X., Qin, M., Wang, Y. \& Ruan, J. (1989). Analysis of menaquinone compound in microbial cells by HPLC. Microbiology [English translation of Microbiology (Beijing)] 16, 176-178.

Xu, J.-L., Liu, Q.-M., Yu, H.-S., Jin, F.-X., Lee, S.-T. \& Im, W.-T. (2009). Hymenobacter daecheongensis sp. nov., isolated from stream sediment. Int J Syst Evol Microbiol 59, 1183-1187.

Zhang, D.-C., Wang, H.-X., Liu, H.-C., Dong, X.-Z. \& Zhou, P.-J. (2006). Flavobacterium glaciei sp. nov., a novel psychrophilic bacterium isolated from the China No.1 glacier. Int J Syst Evol Microbiol 56, 2921-2925.

Zhang, Q., Liu, C., Tang, Y., Zhou, G., Shen, P., Fang, C. \& Yokota, A. (2007). Hymenobacter xinjiangensis sp. nov., a radiation-resistant bacterium isolated from the desert of Xinjiang, China. Int J Syst Evol Microbiol 57, 1752-1756.

Zhang, G., Niu, F., Busse, H.-J., Ma, X., Liu, W., Dong, M., Feng, H., An, L. \& Cheng, G. (2008). Hymenobacter psychrotolerans sp. nov., isolated from the Qinghai-Tibet Plateau permafrost region. Int J Syst Evol Microbiol 58, 1215-1220.

Zhang, L., Dai, J., Tang, Y., Luo, X., Wang, Y., An, H., Fang, C. \& Zhang, C. (2009). Hymenobacter deserti sp. nov., isolated from the desert of Xinjiang, China. Int J Syst Evol Microbiol 59, 77-82. 